\title{
The Struggle for International Financial Standards
}

\author{
An Historical Analysis of Entangling Legalities in Finance
}

\author{
FRANCESCO CORRADINI
}

\subsection{Introduction}

The global financial order is key to our economy but highly fragile. And the norms and institutions to stabilize it are themselves plural and fragmented - in fact, a prime example of multiple bodies of norms coexisting in global governance. This order is characterized by a multiplicity of norms and institutions with various claims to authority, reflecting different priorities and normative orientations. How have actors dealt with the tensions that this plurality generates and where has this left the multiple legalities and their relations?

To answer this question, this chapter examines the recent history of the global administration of financial stability. In the last two decades, this area of financial regulation has been shaped by responses to the perceived risks associated with multiplicity of norms and institutions. The contemporary administration of financial and monetary affairs seems to be surrounded by 'mystery' and 'ambiguity about the relationship between all of the various sources of international regulatory standards'.2 This complexity may partly depend on our limited

I am particularly grateful to Professor Nico Krisch for his generous support and comments on earlier versions of this chapter. I wish to thank the participants in the workshop 'Entangled Legalities', in May 2018, where a first draft of this text was presented, and Tomáš Morochovič for his careful editing of this text. I also gratefully acknowledge the financial support by the SNF, which made this research possible.

${ }^{1}$ D. Kennedy, 'The Mystery of Global Governance', in J. L. Dunoff and J. P. Trachtman (eds), Ruling the World? Constitutionalism, International Law, and Global Governance (Cambridge University Press, 2009), pp. 37-68.

2 A. Riles, 'Managing Regulatory Arbitrage: A Conflict of Laws Approach' (2014) 47 Cornell International Law Journal 63-119, at 80-1. 
understanding of the organizational structures of these relationships and the drivers behind them.

In various contexts of global financial governance, characterized by a significant degree of informality, regulatory decentralization and dynamic institutional interactions, societal actors have shaped different ordering projects in opposition to 'chaos' over time. From a macro perspective, previous studies have helpfully analysed the broad historical and political contexts in which these ordering projects have come about by placing emphasis on 'the power and interests of leading financial powers, domestic political dynamics, and the role of transnational actors'. ${ }^{3}$ Yet we do not quite know the forms through which institutional multiplicity has been organized and with what effects for the overall order. Drawing upon the concepts of this volume, this chapter analyses different forms of entanglements in contexts of global financial regulation, focusing on some of the sites, actor constellations and dynamics behind them. ${ }^{4}$ This chapter uses the term bodies of norms to connect the variety of recommendations, standards, best practices and codes recognized by regulators as factors of financial stability. At various decision-making settings, financial regulators, legal professionals and economic experts disagreed over the identification of the relevant sources of authority and their organizational structures. For example, the prevailing regulatory response that followed the global financial crisis of 2008 was a call for a more or less centralized institutional framework for 'a global banking and financial system'. Some lawyers imagined a new field of international financial law or lex financiera. ${ }^{5}$ Many argued that the International Monetary Fund (IMF) should have institutional primacy, while others regarded the Financial Stability Board (FSB) as the appropriate locus of authority, and yet others suggested that the function of a new World Financial Authority should be allocated. However, opposing views defended a more modest reform through a pluralist approach to ordering. ${ }^{6}$ This chapter questions ambitious attempts at structuring

${ }^{3}$ E. Helleiner, 'Regulating the Regulators: The Emergence and Limits of the Transnational Financial Legal Order', in T. C. Halliday and G. Shaffer (eds), Transnational Legal Orders (Cambridge University Press, 2015), pp. 231-57, p. 235.

${ }^{4}$ See Chapter 1 . Throughout the text, I use 'entanglement' and 'enmeshment' interchangeably.

${ }^{5}$ See, for example, R. M. Lastra, 'Do We Need a World Financial Organization?' (2014) 17 Journal of International Economic Law 787-805.

${ }^{6}$ C. Brummer, Minilateralism: How Trade Alliances, Soft Law, and Financial Engineering Are Redefining Economic Statecraft (Cambridge University Press, 2014). 
and controlling multiplicity through one 'common frame of reference" such as legalization in finance. I contrast this dominant view with the perspective of 'entangled legality' as an alternative way of thinking about relations between multiple kinds of laws populating global finance. From this perspective, the project of legalization is only one among a variety of ways of ordering multiplicity, which may equally contribute to dynamics of enmeshment. While these relations are embedded in a mosaic of interactions between multiple orders, elements of this wider environment form the background of the analysis.

The analysis proceeds as follows. Following this introduction, Section 11.2 describes international financial standards as interrelated bodies of norms and foregrounds how they became entangled in regulatory settings over time. Drawing on public documents from the Bank for International Settlements (BIS), the United Nations (UN) and the IMF, I examine the forms in which these bodies of norms were brought into relation by different actors. In the wake of the Asian financial crisis of 1997, officials at the IMF, UN and BIS made claims ordering institutional fragmentation. In this context, the Financial Stability Forum (FSF) emerged as a 'site of entanglement' and the drafters and users of its Compendium of Standards came to play a central role in organizing relations between norms that were identified as 'international standards'. Against this historical backdrop, Section 11.3 identifies different interface norms and examines how they were used by actors in norm-making and norm-implementation settings. Within the debate on the reform of the international financial architecture, regulatory harmonization and overarching institutions have been dominant responses to the perceived risks of institutional multiplicity. Yet, while there seems to be no consensus over the content of these overarching institutions, competing forms of ordering persist.

\subsection{Contexts of Entanglement in Global Financial Governance over Time}

From the perspective of international legal theory, the actors and structures characterizing global financial regulation differ from those encountered in traditional fields of international law. Three striking features of

\footnotetext{
${ }^{7}$ N. Krisch, 'Pluralism', in J. d'Aspremont and S. Singh (eds), Concepts for International Law (Edward Elgar, 2019), pp. 691-707.

${ }^{8}$ See Chapter 1.
} 
this area of global governance are the informality, multiplicity and dynamic interactions of its norms, institutions and sites of decisionmaking. ${ }^{9}$ In many of these settings, state officials, international organizations, financial institutions and other private actors have recognized norms that often take the form of best practices and standards rather than more established categories of international law. ${ }^{10}$ Equally striking, these norms have often made their appearance in groups, resembling a relatively loose assemblage of 'clusters' of norms. In this respect, the term bodies of norms seems apt to underline their interrelatedness. ${ }^{11}$ Institutional players in global financial regulation have often highlighted this particular feature of international standards by placing emphasis on their interconnectedness and interdependence as commonsensical, just the 'normal' thing to do, ${ }^{12}$ and in doing so they have not found it problematic to blur their boundaries, for example by referring to their own previous work or work done by others.

An early manifestation of the discursive formation of these associations could be observed circa 1995 at the 'Tripartite Group of Banks, Securities and Insurance Regulators'. An informal working group created by the Basel Committee on Banking Supervision, the Tripartite Group facilitated the encounter of national bank, securities and insurance regulators ${ }^{13}$ to exchange information and perform 'intensive cooperation' to address regulatory problems related to 'financial conglomerates'. A senior official from the US Treasury reported that states' competing interests made it challenging to agree on one single supranational institution to provide a solution to these problems. ${ }^{14}$ It is worth mentioning what this

9 C. Brummer, Soft Law and the Global Financial System: Rule Making in the 21st Century (Cambridge University Press, 2015), see in particular chapter 2. Annelise Riles has described 'global financial regulation' as a 'global system that is inherently pluralistic'. A. Riles, 'Is New Governance the Ideal Architecture for Global Financial Regulation?', in C. Goodhart, D. Gabor, J. Vestergaard and I. Ertürk (eds), Central Banking at a Crossroads: Europe and Beyond (Anthem Press, 2014), pp. 245-64.

10 According to Brummer, the three forms of soft financial law are: best practices, data and information sharing agreements. Brummer, Minilateralism, pp. 96-8.

11 See Chapter 1.

12 'The recognition of authority can flow from many sources: it can result from rational calculus, normative internalization or a mere acceptance as "normal".' N. Krisch, 'Liquid Authority in Global Governance' (2017) 9 International Theory 237-60, at 242.

${ }^{13}$ For the list of members, see Basel Committee, 'The Supervision of Financial Conglomerates: A Report by the Tripartite Group of Bank, Securities and Insurance Regulators' (July 1995), at 67-8.

14 'Since a single global financial regulator is not a feasible idea from our point of view due to sovereignty concerns, we had to look at the problem in terms of promoting regulatory 
informal working group aimed at innovating against. Until then, challenges associated with 'financial conglomerates', in particular the 'regulatory arbitrage' problem, had been dealt with from the perspective of different 'regulatory groups. ${ }^{15}$ In contrast, the Tripartite Group responded to pluralism 'from a joint perspective'. The making of this 'joint perspective' in opposition to the 'different approaches adopted by supervisors' enabled national financial regulators to 'synthetize' the work that had previously been done.

This synthesis was recognized by members of the Basel Committee on Banking Supervision (BCBS), the Technical Committee of the International Organization of Securities Commission (IOSCO) and the International Association of Insurance Supervisors (IAIS) as a 'sound basis for further collaborative efforts ${ }^{16}$ which led to the creation, in 1996, of a 'Joint Forum on Financial Conglomerates'. ${ }^{17}$ The Joint Forum was an informal setting where senior bank, insurance and securities supervisors from thirteen countries ${ }^{18}$ assembled to 'exchange information' and practice 'supervisory coordination'. The Basel Committee's Minimum Standards for the Supervision of International Banking Groups and their Cross-border Establishments, IOSCO's Principles for Memoranda of Understanding and IAIS 'Insurance Concordat' - Principles Applicable to the Supervision of International Insurers and Insurance Groups and their Cross-border Establishments - were jointly recognized by members of the Joint Forum as 'a common set of principles' to practice exchange of information among supervisors. ${ }^{19}$

cooperation and information exchange among regulators'. W. Murden, 'Banking Supervision and Government Policy: The Role of Regulators in International Financial Reform' (1999) 4 Fordham Journal of Corporate \& Financial Law 35-40.

15 These actors were 'the Basle Committee on Banking Supervision, the Working Group of the Conference of Insurance Supervisors of the European Economic Community, the Technical Committee of the International Organization of Securities Commissions (IOSCO), the Banking Advisory Committee of the Commission of the European Communities and the Insurance Committee of the Commission of the European Communities'. Basel Committee, 'The Supervision of Financial Conglomerates', 11.

16 Ibid., ii.

17 Basel Committee, 'Supervision of Financial Conglomerates: Papers Prepared by the Joint Forum on Financial Conglomerates' (February 1998).

${ }^{18}$ In 1998, these countries were: Australia, Belgium, Canada, France, Germany, Italy, Japan, the Netherlands, Spain, Sweden, Switzerland, the United Kingdom and the United States. The EU Commission participated as an observer. See also Brummer, Soft Law and the Global Financial System, p. 82.

19 Consultation documents released by the Basle Committee on Banking Supervision, see Basel Committee, 'Supervision of Financial Conglomerates'. 
Another informal site of interaction between ministers of finance, central bankers from 'industrial countries ${ }^{20}$ and 'emerging markets ${ }^{21}$ and representatives from international institutions and international standards organizations ${ }^{22}$ was the Working Party on Financial Stability in Emerging Market Economies. In 1997, under the chairmanship of Mario Draghi, the Working Party issued a report on the banking sector in emerging markets, referring to 'a corpus of sound principles and practices $^{23}$ by which they brought norms produced by international groupings' into relation. ${ }^{24}$

\subsubsection{Ordering Bodies of Norms after Financial Crises}

The anecdotal evidence just presented suggests that informal settings of interaction between institutional players have also been 'sites of entanglement' where bodies of norms have been pieced together through social 'practices of recognition and deference'. ${ }^{25}$ This section takes a closer look at similar statements pronounced by situated actors at three different regulatory sites: the IMF, the UN and the BIS, to examine whether and how, in the aftermath of financial crises, dynamics of entanglement played out there. ${ }^{26}$ Financial crises have often been moments of change

${ }^{20}$ France, Germany, Japan, the Netherlands, Sweden, the United Kingdom and the United States.

21 Argentina, Hong Kong, Singapore, Indonesia, Korea, Mexico, Poland, Singapore, Thailand.

22 These actors were Representatives of the Basel Committee on Banking Supervision, the International Accounting Standards Committee (IASC) and the International Organization of Securities Commissions (IOSCO) and staff members of the Bank for International Settlements (BIS), the European Commission, the International Monetary Fund (IMF), the Organization for Economic Co-operation and Development (OECD) and the International Bank for Reconstruction and Development (World Bank).

${ }^{23}$ Working Party on Financial Stability in Emerging Market Economies, 'Report on Financial Stability in Emerging Market Economies, a Strategy for the Formulation, Adoption and Implementation of Sound Principles and Practices to Strengthen Financial Systems' (April 1997). The members of the Working Party are listed on pp. 101-2 of the report.

24 These actors were: the IASC, IOSCO, the Basel Committee on Banking Supervision of the Group of Ten (G10) central banks, the Committee on Payment and Settlement Systems of the G10 central banks, International Association of Insurance Supervisors.

${ }^{25}$ Krisch, 'Liquid Authority in Global Governance', 249.

${ }^{26}$ We might expect to observe different or similar forms of ordering plurality in other settings, too. See Chapter 1. 
in the historical development of the global financial order. ${ }^{27}$ They have also been key historical contexts in which regulatory actors formulated reform efforts to reorder institutional multiplicity. For example, in response to the Asian financial crisis of 1997, IMF jurists and economists placed emphasis on 'international standards and codes' against the different domestic laws that some IMF officials saw as problematic for financial stability. ${ }^{28}$ However, the definition of these bodies of norms and the articulation of their relations were neither uncontroversial nor necessary decisions but occurred in multiple and incremental steps.

In 1997, Morris Goldstein, ${ }^{29}$ an IMF economist, published a book entitled The Case for an International Banking Standard ${ }^{30}$ which strengthened the project of international harmonization in the banking area. Goldstein argued for the creation of a new international banking standard (IBS) through the combination of existing norms and practices. The envisaged standard had to be shaped through 'vigorous cross-agency cooperation' rather than by one single decision-maker, and be comprehensive and broad in scope and design. The Basel Committee 'should not be the only group working on an IBS $^{31}$ - instead, the new norm should draw not only on the expertise and norms of good banking supervision by the Basel Committee but also on those of international accounting and transparency, traditionally considered to fall under the jurisdiction of the International Accounting Standards Committee (IASC) and IMF respectively. ${ }^{32}$ Goldstein's approach straddled boundaries between standards traditionally considered to be confined to well-defined domains. The IBS would only aim at 'partial' as opposed to 'full' international harmonization of banking standards, leaving 'room for states to maintain their

${ }^{27}$ Helleiner, 'Regulating the Regulators'. See also C. Brummer and M. Smallcomb, 'Institutional Design: The International Architecture', in N. Moloney, E. Ferran and J. Payne (eds), The Oxford Handbook of Financial Regulation (Oxford University Press, 2015).

${ }^{28}$ On the historical background of the trajectory towards international standards, see R. P Delonis, 'International Financial Standards and Codes: Mandatory Regulation without Representation' (2004) 36 New York University Journal of International Law and Politics 563-604.

29 Deputy Director of the IMF Research Department (1987-94).

30 M. Goldstein, The Case for an International Banking Standard (Peterson Institute for International Economics, 1997).

${ }^{31}$ Ibid., at 53 .

32 Ibid., at 35. 
national preferences towards risk, as well as to maintain some of their institutional diversity. ${ }^{33}$

Actors associated with the Bretton Woods institutions began referring to 'internationally accepted best practices' and 'international standards' to bring together select bodies of norms that they recognized as central features of the new international financial architecture. ${ }^{34}$ IMF officials referred to 'international financial standards' to link multiple bodies of norms deemed relevant to 'the soundness of the financial system'. ${ }^{35}$

An international consensus on how standards relate to each other and with domestic legal orders was shaped through various tools, including monitoring practices performed by international financial institutions. Through these practices, IMF and World Bank officials connected norms produced by the IMF itself, the World Bank or other international standard-setting organizations and associated them with domestic legal orders in developed and developing economies. ${ }^{36}$ In particular, the

33 Ibid.

34 Michel Camdessus, former managing director of the IMF, referred to internationally accepted best practices' to bind together the Basel Adequacy standards, internationally accepted accounting standards and disclosure rules. M. Camdessus, 'The Role of the IMF: Past, Present, and Future - Speech' (13 February 1998). He further stated: 'the Fund has been working to help disseminate a set of "best practices" in the banking area - as developed by the Basle Committee - so that standards and practices that have worked well in some countries can be adapted and applied in others. These efforts will now be stepped up.' See address by M. Camdessus to the Parliamentary Assembly of the Council of Europe, 'From the Asian Crisis toward a New Global Architecture' (23 June 1998). Stanley Fisher, first deputy managing director of the IMF (1994-2001) expressed similar ideas: 'As we help countries strengthen their financial systems, we need guideposts to judge what has been achieved and what remains to be done. This requires international standards against which to assess the soundness and stability of financial systems. There are many players in the international community with a keen interest in such standards, and their development requires the active participation of both private and official bodies, domestic and international [...] But there has been a growing recognition of the links between their work and the consequent need for collaboration [...] the main contribution of the Fund is in encouraging the implementation of standards that have been determined by others and then using them in our work on the assessment of financial systems [...] Standards cannot be written in stone. They are bound to evolve in the light of experience.' S. Fischer, 'The IMF and the Financial Sector - Introductory Remarks' (5 June 2000).

35 These bodies of norms were on: data dissemination, fiscal transparency, monetary and fiscal policies, banking supervision, securities market regulation, insurance regulation, accounting, auditing, bankruptcy and corporate governance. See IMF Policy Development and Review Department, 'Progress Report Developing International Standards' (1999).

36 T. Halliday, 'Legal Yardsticks: International Financial Institutions as Diagnosticians and Designers of the Law of Nations', in K. Davis, A. Fisher, B. Kingsbury and S. E. Merry 
creation of the Financial Sector Assessment Program (FSAP) authorized IMF officials to link standards that they recognized as relevant for a safe international financial system and bring them into relation with domestic legal orders. ${ }^{37}$ One important outcome of monitoring practices performed in the context of FSAP is the production of a report on 'Financial System Stability Assessment'. This report is subsequently taken into account when the IMF conducts 'bilateral surveillance' and performs 'consultations' with domestic authorities being assessed, under Article IV of the IMF Articles of Agreement. ${ }^{38}$ Through these monitoring practices, IMF officials have deferred to the authority of twelve international standards setters ${ }^{39}$ they consider to be 'relevant' in the context of their work. ${ }^{40}$ The report resulting from these monitoring practices verifies and strengthens the recognition of standards but their recommendations also provide 'feedback' to the standard-setting organizations that produce standards. ${ }^{41}$

Previous historical analyses of international financial institutions have argued that the IMF's monitoring practices have normative power and

(eds), Governance by Indicators: Global Power through Quantification and Rankings (Oxford University Press, 2012), pp. 180-216, at pp. 200-2; A. Feibelman, 'Law in the Global Order: The IMF and Financial Regulation' (2017) 49 New York University Journal of International Law and Politics 687-746.

37 FSAPs Reports consist of three 'Volumes'. Volume III is titled 'Assessment of Observance of International Standards and Codes'. On the operation of FSAP and Reports on the Observance of Standards and Codes, see the perspective of François Gianviti, former General Counsel of the IMF, in F. Gianviti, 'Legal Aspects of the Financial Sector Assessment Program' (2005) 3 Current Developments in Monetary and Financial Law 219.

38 Gianviti, 'Legal Aspects of the Financial Sector Assessment Program'.

39 'The IMF has recognized 12 areas and associated standards as useful for the operational work of the Fund and the World Bank. These comprise accounting; auditing; anti-money laundering and countering the financing of terrorism (AML/CFT); banking supervision; corporate governance; data dissemination; fiscal transparency; insolvency and creditor rights; insurance supervision; monetary and financial policy transparency; payments systems; and securities regulation; AML/CFT was added in November 2002.' See www .imf.org/external/NP/rosc/rosc.aspx.

40 'An FSAP assessment will look at the financial sector's legislative underpinnings to evaluate regulatory capacity and practice. This will include a systematic assessment of compliance with the Basel Core Principles for Effective Banking Supervision, transparency practices in monetary and financial policies, and - if relevant - standards for securities markets, insurance, and payment systems. Other legal and institutional issues that bear on the financial sector may also be reviewed.' P. Hilbers, 'The IMF/World Bank Financial Sector Assessment Program', IMF, February 2001.

${ }^{41}$ IMF and World Bank, 'Financial Sector Assessment Program - Review, Lessons, and Issues Going Forward' (24 February 2005). 
'hegemonic' features. In particular, IMF conditionality has discursively reinforced colonial relations of domination reinscribing the North-South divide. ${ }^{42}$ Indeed, 'globalization [...] requires the replacement of numerous national laws and jurisdictions by uniform global standards in order to remove the barriers to capital accumulation at the global level'. ${ }^{43}$ From these perspectives, conditionality operates as a 'path to entanglement' based on coercion, ${ }^{44}$ which is often made invisible by taking the form of 'incentives'. For example, according to the IMF, it is 'in countries' own interest to adopt and implement internationally recognized standards and codes' ${ }^{45}$ For borrowing countries, highlighting linkages with international standards becomes crucial to persuade institutional creditors of their creditworthiness. These linkages appeared for example in the letters of intent' of Korea, Indonesia and Thailand as they requested institutional creditors' support to recover from an economic crisis. ${ }^{46}$ Similarly, the government of Turkey deferred to the authority of international standards ${ }^{47}$ and officials from Colombia gave weight to international standards on auditing, the Basel core principles and codes of conduct on money laundering and terrorism financing. ${ }^{48}$ From the perspective of states seeking financial support there have been incentives and constraints to tie their domestic legal orders to international financial standards, although the latter are formally non-binding. ${ }^{49}$ In this context, entanglement was driven by both states' rational interests and the

${ }^{42}$ S. Pahuja, 'Technologies of Empire: IMF Conditionality and the Reinscription of the North/South Divide' (2000) 13 Leiden Journal of International Law 749-813.

${ }^{43}$ B. S. Chimni, 'Marxism and International Law: A Contemporary Analysis' (1999) 34 Economic and Political Weekly 337-49; B. S. Chimni, 'International Institutions Today: An Imperial Global State in the Making' (2004) 15 European Journal of International Law $1-37$.

44 Brummer and Smallcomb, 'Institutional Design'.

${ }^{45}$ See www.imf.org/en/About/Factsheets/Sheets/2016/08/01/16/25/Standards-and-Codes.

${ }^{46}$ Camdessus, 'The Role of the IMF'.

${ }^{47}$ Letter of Intent of the government of Turkey (2001), www.imf.org/external/np/loi/2001/ tur/02/.

${ }^{48}$ Letter of Intent, Memorandum of Economic and Financial Policies, and Technical Memorandum of Understanding of Colombia (2002), www.imf.org/external/np/loi/ 2002/col/01/index.htm.

${ }^{49}$ On the idea of conditioning the disbursement of funds to the adherence to such standards, see B. J. Eichengreen, Toward a New International Financial Architecture: A Practical Post-Asia Agenda (Peterson Institute for International Economics, 1999). Giovanoli has called these determinants 'official incentives' (FSAP) and 'unofficial incentives' (market expectations). See M. Giovanoli, 'The Reform of the International Financial Architecture after the Global Crisis' (2009) 42 New York University Journal of International Law and Politics 81-123, at 118-19. 
realization of their position in a relation of economic dependency, close to a material condition of coercion. ${ }^{50}$ In the UN context, officials represented the 'international financial architecture' as a 'system'. For example, a UN Task-Force led by José Antonio Ocampo ${ }^{51}$ argued that 'the international financial system is an organic whole and requires a comprehensive approach, ${ }^{52}$ From this systemic perspective, the UN Task-Force articulated a vision of the international financial architecture in close connection with human rights laws and UN institutions. UN officials did not invoke the UN Charter but relied instead on the provisions of the Covenant on Economic, Social and Cultural Rights to create normative expectations for all the subsystems constituting the international financial architecture.

At the BIS, 'international standards' were also invoked against institutional pluralism. ${ }^{53}$ Here, Hans Tietmeyer ${ }^{54}$ criticized the 'fragmented supervisory structures' characterizing the status quo and suggested improve 'international cooperation and coordination' by 'bringing together the major international institutions and key national authorities involved in financial sector stability' and to include 'emerging market economies' ${ }^{55}$ Arguing that the model of the Joint Forum ${ }^{56}$ had to be applied 'in a comprehensive manner', Tietmeyer referred to 'accepted best practices' to bind the 'Core Principles issued by both the BCBS and IOSCO, and those being developed by other international groupings' together. ${ }^{57}$ Based on Tietmeyer's report, the Group of Seven (G7) created the Financial Stability Forum. ${ }^{58}$ The new organization enabled the encounter of a large number of actors, mainly 'public' but also 'private'

${ }^{50}$ On these different paths to entanglement, see Chapter 1.

${ }^{51}$ Report of the Task-Force of the Executive Committee on Economic and Social Affairs of the United Nations, 'Towards a New International Financial Architecture' (21 January 1999), 14-15.

52 Ibid., 7.

${ }^{53}$ Institutional pluralism seems the only form of pluralism considered by participants in international financial regulation reform. This form of pluralism is different from 'systemic pluralism'. On this conceptual distinction, see Krisch, 'Pluralism', pp. 695-8.

${ }^{54}$ Economist and former president of the Deutsche Bundesbank (1993-9).

55 H. Tietmeyer, 'Report on International Cooperation and Coordination in the Area of Financial Market Supervision and Surveillance' (11 February 1999).

56 On the Joint Forum, see Section 11.2.

57 Tietmeyer, 'Report on international cooperation and coordination'.

58 On the creation of the Financial Stability Forum, see Brummer, Soft Law and the Global Financial System, p. 74. See also Helleiner, 'Regulating the Regulators'. 
ones. ${ }^{59}$ Andrew Crockett ${ }^{60}$ was appointed as first chairman for a threeyear term. ${ }^{61} \mathrm{~A}$ member of the Board of Trustees of the International Accounting Standards Board (2000-3), an organization with the mission to create a global financial reporting standard, ${ }^{62}$ Crockett was in favour of global approaches to ordering multiplicity ${ }^{63}$ and regarded international financial standards as 'interrelated'. ${ }^{64}$

\subsubsection{Competing Ordering Projects}

At their second meeting, FSF members introduced a 'Compendium of Standards', describing it as 'a common reference for the various economic and financial guidelines, principles, and codes of good practices that are internationally accepted as relevant to sound, stable and wellfunctioning financial systems'. ${ }^{65}$

59 These actors were: 'the finance minister, central bank governor, and a supervisory authority from each of the G-7 countries, as well as representatives from the IMF, World Bank, Bank for International Settlements ("BIS"), Organization for Economic Cooperation and Development ("OECD"), Basel Committee on Banking Supervision ("BCBS"), International Accounting Standards Board ("IASB"), International Association of Insurance Supervisors ("IAIS"), International Organization of Securities Commissions ("IOSCO"), Committee on Payment and Settlements Systems ("CPSS"), and Committee on the Global Financial System ("CGFS"). After its creation, the FSF added the European Central Bank, and additional national members Australia, Hong Kong, the Netherlands, and Switzerland.' E. Carrasco, 'The Global Financial Crisis and the Financial Stability Forum: The Awakening and Transformation of an International Body Global Financial and Economic Crisis Symposium' (2010) 19 Transnational Law \& Contemporary Problems 203-20, at 206.

60 Andrew Crockett worked at the IMF (1972-89), was executive director of the Bank of England (1989-93) and worked as general manager of the BIS (1994-2003).

${ }^{61}$ Communiqué of G7 Finance Ministers and Central Bank Governors, 20 February 1999, Petersberg, Bonn. On the role of Tietmeyer and the BIS in the creation of the FSF, see C. Brummer, 'A Theory of Everything: A Historically Grounded Understanding of Soft Law and the BIS', in C. Borio, S. Claessens, P. Clement, R. McCauley and H. Shin (eds), Promoting Global Monetary and Financial Stability: The Bank for International Settlements after Bretton Woods, 1973-2020 (Cambridge University Press, 2020), pp. 112-33.

${ }^{62}$ K. Camfferman and S. A. Zeff, Aiming for Global Accounting Standards: The International Accounting Standards Board, 2001-2011 (Oxford University Press, 2015).

63 '[A] set of global financial reporting standards that is accepted and, equally importantly, widely and effectively implemented is a critical missing pillar in the emerging international financial architecture.' A. Crockett, 'Towards Global Financial Reporting Standards: A Critical Pillar in the International Financial Architecture' (BIS, 2002).

${ }^{64}$ A. Crockett, 'International Financial Arrangements: Architecture and Plumbing' (BIS, 15 November 1999).

65 'The Compendium is a joint product of the various standard-setting bodies represented on the Forum. It will be reviewed and updated on an ongoing basis and is envisaged to cover a range of areas relevant to sound and stable financial systems: (a) transparency of 
Yet the FSF's response to institutional pluralism was not uncontroversial. Born in the midst of controversies over a new 'international financial architecture, ${ }^{66}$ the Compendium triggered opposing reactions. Some interpreted it as 'a single global rule book' providing 'reference rules' for the operation of financial markets. ${ }^{67}$ BIS officials supported the 'pragmatic multitherapy' approach to ordering provided by the Compendium in contrast to an institutional framework. ${ }^{68}$ However, some lawyers sought to embed its prescriptions within an institutional structure, in particular within the jurisdiction of the rule of law. ${ }^{69}$ For example, Mario Giovanoli ${ }^{70}$ invoked the rule of 'international law' as the frame of reference to govern institutional multiplicity. ${ }^{71}$ The legalization project was similar to the idea of 'international regulation' under a new 'World Financial Authority' advocated by economists Barry Eichengreen, Lance Taylor and John Eatwell. ${ }^{72}$ Two institutional innovations provoked by the 2008 financial crisis had implications for reorganizing multiplicity. The Group of Twenty (G20) replaced the G7 as a central forum of economic diplomacy and transformed the FSF in the Financial Stability Board, enabling participation of state representatives from the

fiscal, monetary, and financial policies; (b) dissemination of economic and financial data; (c) regulation and supervision of banking, securities, and insurance; (d) disclosure, transparency, and risk management practices of financial institutions; (e) corporate governance, accounting, auditing, and bankruptcy; and (f) payment and settlement systems.' Background brief made available to the press at the second meeting of the Financial Stability Forum, 15 September 1999.

66 J. Eatwell and L. Taylor, Global Finance at Risk: The Case for International Regulation (Polity Press, 2000); Eichengreen, Toward a New International Financial Architecture; M. Giovanoli (ed.), International Monetary Law: Issues for the New Millennium (Oxford University Press, 2000).

${ }^{67}$ G. Walker, 'A New International Architecture and the Financial Stability Forum', in R. M. Lastra (ed.), The Reform of the International Financial Architecture (Kluwer Law International, 2000).

${ }^{68}$ A. Icard, 'Strengthening Financial Stability: Institutional Approach or Pragmatic Multitherapy?' (BIS, 1999).

69 On law as a variant of jurisdiction, see S. Pahuja, 'Laws of Encounter: A Jurisdictional Account of International Law' (2013) 1 London Review of International Law 63-98.

${ }^{70}$ General Counsel of the BIS from 1989 to 2005.

71 ' $[\mathrm{I}] \mathrm{t}$ is therefore important to examine all the possibilities which might strengthen international financial standards by granting them an appropriate legal status in international law.' Giovanoli, International Monetary Law, p. 59.

72 Eatwell's and Taylor's project was to construct 'a framework within which a coherent international policy can be worked out at implemented'. Eatwell and Taylor, Global Finance at Risk. For a similar perspective, see A. Kern, R. Dhumale and J. Eatwell, Global Governance of Financial Systems: The International Regulation of Systemic Risk (Oxford University Press, 2006), at xiii. 
G20. ${ }^{73}$ These institutional rearrangements meant that a larger group of actors was able to assemble and shape the Compendium by recognizing new standards. However, the majority of FSB members were (and still are) public regulators, and regulators from the Global North seem to have greater influence than those from other regions. Furthermore, interactions with market participants and other private actors have remained limited. ${ }^{74}$

While the G20 and the FSB provided a limited 'vertically integrated' structure of economic decision-making, ${ }^{75}$ the two organizations also sidelined ambitious efforts to create overarching institutions, including through a reform of the IMF. Calls for 'international harmonization' and attempts to 'reset' the 'international financial (non-) system ${ }^{76}$ became the dominant responses to institutional heterogeneity. ${ }^{77}$ The project to bring multiplicity within the jurisdiction of international law and international lawyers has been one manifestation of this trajectory towards legalization. ${ }^{78}$ Finding a contradiction between a 'global' financial system and the lack of a coherent institutional framework, many lawyers called for a global 'ruler' in international finance. In keeping with a professional sensibility shared by many jurists, the legalization project has sought to conceptualize 'international financial law' as the frame of reference to contain the panoply of norms and practices in finance. From the standpoint of the legalization project, sometimes this heterogeneity is framed

${ }^{73}$ On the transformation of the FSF into the FSB, see E. Carrasco, 'The Global Financial Crisis and the Financial Stability Forum'; S. Gadinis, 'The Financial Stability Board: The New Politics of International Financial Regulation' (2013) 48 Texas International Law Journal 158-75.

74 As Annelise Riles has observed: 'the FSB process has mainly engaged representatives of governments and international bureaucracies, with private parties participating only through more attenuated opportunities for public comment'. Riles, 'Is New Governance the Ideal Architecture for Global Financial Regulation?', 257.

75 Brummer, 'A Theory of Everything'.

76 J. A. Ocampo, Resetting the International Monetary (Non)System: A Study Prepared by the United Nations University World Institute for Development Economics Research (UNUWIDER, 2017).

${ }^{77}$ For an analysis and critique of approaches to harmonization, see Riles, 'Managing Regulatory Arbitrage', 77-87.

78 T. Cottier et al., The Rule of Law in Monetary Affairs: World Trade Forum (Cambridge University Press, 2014); for a critique of this tendency in international economic interactions, see A. Lang, 'Rule of Law in International Economic Relations', in T. Cottier and K. N. Schefer (eds), Elgar Encyclopedia of International Economic Law (Edward Elgar, 2017). 
as a 'black hole'. ${ }^{79}$ This expression refers to an absence of traditional frames of international law, and the contrast is often made with more established fields of international economic law, such as international trade and investment law.

The rationale underlying this approach is that international solutions are needed for international problems ${ }^{,}{ }^{80}$ Under this view, the IMF should become the institutional centre of the international monetary and financial system. Proponents of this way of thinking have regarded international trade law as a model to design a rule of law-based system in international financial and monetary interactions. The envisaged system would provide for a 'World Financial Authority' and an international dispute settlement mechanism to fill the 'black hole' in international law and finance.

Others have seen the FSB as a more suitable site and actor to promote the movement of international financial law 'from a heterarchical setting to a more centralized and coordinated pattern'. ${ }^{81}$ When articulating their position in relation to multiple bodies of norms, FSB members have described themselves as providers of a 'framework for strengthening adherence to international standards'. ${ }^{82}$ They have called for 'international coordination' through practices of 'international harmonization' among domestic regulators. Another approach has sought to articulate a vision of the global financial order against institutional pluralism through the notion of 'multilayered governance'. This perspective seeks to identify 'common core values shared by the international community' as guiding principles for the allocation of regulatory power among the various layers of governance. ${ }^{83}$ Similar to the legalization project, advocates of this mode of ordering start from an intra-systemic perspective from which

79 'In finance, we have a "black hole" with few formal international rules and no adequate system to deal with cross-border crisis or conflicts.' Lastra, 'Do We Need a World Financial Organization?', 797.

80 Ibid., 804.

81 C. de Stefano, 'Reforming the Governance of International Financial Law in the Era of Post-Globalization' (2017) 20 Journal of International Economic Law 509-33. See also M. De Bellis, 'Relative Authority in Global and EU Financial Regulation: Linking the Legitimacy Debates', in J. Mendes and I. Venzke (eds), Allocating Authority: Who Should Do What in European and International Law? (Hart Publishing, 2018), pp. 241-70.

82 See FSB, 'Promoting Global Adherence to International Cooperation and Information Exchange Standards' (2010).

${ }^{83}$ R. Weber, 'Multilayered Governance in International Financial Regulation and Supervision', in T. Cottier, J. H. Jackson and R. M. Lastra (eds), International Law in Financial Regulation and Monetary Affairs (Oxford University Press, 2012), pp. 151-70, at 158-69. For a similar perspective, see P. E. Avgouleas, Governance of Global Financial 
they formulate a global regulatory framework to construct full coherence among the different parts of the overall system.

Yet competing visions have been sceptical of legalization as a workable way of organizing diversity in global financial governance. Critics have contended that the idea of one overarching institution - a 'global sheriff $^{84}$ of sorts - seems out of touch with the heterogeneity and competition of national concerns and interests driving global business firms operating in modern global finance. ${ }^{85}$ For an environment characterized by 'increasing multipolarity' and 'dispersed economic power and interests', a model of pragmatic 'minilateralism' may be a better fit than an institutional grand design. ${ }^{86}$ The project of harmonization sought to provide a centre of gravity - a new 'architecture' - against or irrespective of the autonomous norms and practices of legal technique and selfregulation that market actors, including private organizations such as the International Swaps and Derivatives Association, use in their financial business operations on over-the-counter derivatives but that fly under the radar of overarching institutions. ${ }^{87}$

\subsection{Responding to Multiplicity in Global Financial Governance}

Against the historical and doctrinal background of some of the projects of reordering global financial regulation discussed so far, this section looks more closely at the interface norms associated with projects to respond to multiplicity in the different institutional settings examined.

\subsubsection{The Project of Harmonization: Overarching Norms and Reception Norms}

The historical process of associating bodies of norms after the Asian financial crisis and global financial crisis was partly defined by competing

Markets: The Law, the Economics, the Politics (Cambridge University Press, 2012), chapter 8.

${ }^{84}$ R. M. Lastra, International Financial and Monetary Law (Oxford University Press, 2015).

85 Brummer argues that the idea of a single global authority is impractical because 'states are unlikely to cede power to a global financial regulator', Brummer, Soft Law and the Global Financial System, p. 328. See also L. Baxter, 'Understanding the Global in Global Finance and Regulation', in R. Buckley, E. Avgouleas and D. Arner (eds), Reconceptualising Global Finance and Its Regulation (Cambridge University Press, 2016), pp. 28-48.

${ }^{86}$ Brummer, Minilateralism.

87 A. Riles, Collateral Knowledge: Legal Reasoning in the Global Financial Markets (University of Chicago Press, 2011). 
efforts to reimagine the global financial order. Two manifestations here were the projects of 'international regulation' and 'legalization' advocated by actors associated with the IMF institutional context. Though the two projects had different nuances, they adopted an intra-systemic perspective to govern institutional relations from a central vantage point. Indeed, they both imagined a common integrating principle - 'international regulation' or 'international law' - at the apex of the 'international financial architecture'. Thus, the philosophy of overarching norms informed both reform projects. ${ }^{88}$ In the UN context, the approach to ordering followed a somewhat similar logic. Relying on a similar form but a different content of interface norms, the UN Task-Force referred to 'sustainable human development' and 'democracy ${ }^{89}$ as principles governing the decision-making process within the envisaged international financial architecture. The UN Task-Force interpreted 'International codes of conduct, improved information, and enhanced financial supervision and regulation' as an overarching framework governing the system. However, they went so far as to argue that the framework would include international standards to combat money and asset laundering as well as corruption and tax evasion' but also ensure 'consistency' with human rights, particularly those in the International Covenant on Economic, Social and Cultural Rights. ${ }^{90}$ Moreover, the UN Task-Force went beyond a purely intra-systemic perspective to take into view relationships between the international financial system and different domestic legal systems. While emphasizing the 'global' character of 'financial regulation and supervision', the UN Task-Force also gave weight to domestic legal orders and their 'different national financial structure and traditions as regards financial regulation and supervision'. ${ }^{91}$

${ }^{88}$ On 'overarching norms', see Chapter 1.

89 'We must emphasize that any reform of the international financial system ought to be based on a broad discussion, involving all countries, and a clear agenda, including all key issues. The process must ensure that the interests of all groups of developing and transition economies, including poor and small countries, are adequately represented. The United Nations, as a universal and the most democratic international forum, should play an important role in these discussions and in the design of the new system.' TaskForce of the Executive Committee on Economic and Social Affairs of the United Nations, 'Towards a New International Financial Architecture', 9.

90 Ibid., 15.

91 Task-Force of the Executive Committee on Economic and Social Affairs of the United Nations, 'Towards a New International Financial Architecture', 15. 
While it is not obvious that UN officials perceived domestic legal systems as integrated parts within the 'international financial system', it seems more plausible that they relied on the more flexible interface norm of 'taking into account' to connect 'domestic' and 'international' systems. ${ }^{92}$ When bringing these legal orders into a mutual relation, the UN body of experts relied on reception norms in so far as they required that 'due account should be taken' of local circumstances in domestic legal systems. ${ }^{93}$ The project of international harmonization was never uncontroversial and provoked tensions with domestic sites of governance, as evidenced by the attitudes of some national authorities creating resistance to international standards. For instance, the deputy governor of the Reserve Bank of India articulated a 'national law perspective' highlighting the 'discretion' and 'considerable flexibility' that officials in India had while interpreting 'general principles' in international standards and bringing them in relation to the domestic legal order. ${ }^{94}$ This language is similar to reception norms in its effect of creating distance between international standards and the Indian domestic legal system.

After the 2008 financial crisis, the reform of the international financial architecture emerged as a new site of struggle between lawyers, economists and policy-makers to redefine interactions between bodies of norms. ${ }^{95}$ In this context, forms of entanglement mirrored the dominant response to multiplicity, in particular at the IMF, that followed the Asian financial crisis of 1997. Seeking more centralization and unity than diversity and collaboration, many actors sought to frame multiplicity from a systemic perspective, adopting a functional analysis. They have often done so by deploying interface norms such as the 'rule of law'. ${ }^{96}$ Particularly in Europe, a similar reliance on overarching norms characterized most responses to institutional diversity, ${ }^{97}$ placing emphasis on

92 Chapter 1.

93 Task-Force of the Executive Committee on Economic and Social Affairs of the United Nations, 'Towards a New International Financial Architecture', 15.

94 ' $[\mathrm{T}]$ here are several reasons to be circumspect about the role of standards and codes as primary instruments of enhancing international financial stability.' See Y. V. Reddy, 'Legal Aspects of International Financial Standards - National Law Perspective' (BIS Review, 2002).

95 The financial press also promoted the idea of a formal amendment of Articles of Agreement to transform the IMF in the new 'guardian of the global financial system'. See 'Wanted: A Guardian of the World's Financial System', Financial Times (April 2007).

96 Cottier et al., The Rule of Law in Monetary Affairs.

97 C. Reinhart and K. Rogoff, 'Regulation Should Be International', Financial Times (November 2008). 
regulatory coherence and centralization of authority. ${ }^{98}$ For example, the 'de Larosière Report' ${ }^{\text {'99 }}$ proposed an integrated approach to financial regulation in Europe and at the international level. ${ }^{100}$ Noting the 'evident lack of a coherent framework', the authors of the report recommended that a 'reformed FSF would be in the best position for coordinating the work of the various international standard-setters in achieving international regulatory consistency'. ${ }^{101}$ They envisaged a treaty establishing a 'full international standard-setting authority' creating binding obligations for states and monitored by the IMF through its Article IV Consultations powers. ${ }^{102}$ At a more general level, this argumentative structure reflects the imagery suggested by proponents of constitutionalism in controversies over the shape of postnational law and politics. Sharing a similar ambition, many theorists of international financial regulation have sought to construe a legal system to 'contain' the plurality of sources characterizing global financial governance. ${ }^{103}$

\subsubsection{Making the Compendium of Standards: Straddling Practices and Reception Norms}

As a 'joint product', the Compendium was produced by an ad hoc TaskForce on Implementation of Standards (Task-Force), a group of specialists $^{104}$ that had been assembled by the FSF with the aim of developing a 'strategy' to strengthen 'international consensus on key standards' for financial stability. To shape the form and content of the Compendium, the Task-Force drew upon 'prior work' by the IMF, World Bank and standard-setting bodies in 'promulgating and assessing observance of standards'. ${ }^{105}$ Given the plurality of 'economic and financial standards'

${ }^{98}$ M. Giovanoli and D. Devos (eds), International Monetary and Financial Law: The Global Crisis (Oxford University Press, 2011).

99 Report by the High-Level Group on Financial Supervision in the EU (Chaired by Jacques de Larosière), 2009, at 59. See chapter 4 of the report (Global Repair, Promoting Financial Stability at the Global Level), 2009.

100 The financial press appreciated the 'step-by-step' approach advocated by the de Larosière group. See, 'A Single Rulebook', Financial Times (February 2009).

101 Report by the High-Level Group on Financial Supervision in the EU.

102 Ibid.

${ }^{103}$ N. Krisch, Beyond Constitutionalism: The Pluralist Structure of Postnational Law (Oxford University Press, 2010), chapter 2.

${ }^{104}$ For the full list of members of the Task-Force, see FSF, 'Issue Paper of the Task-Force on Implementation of Standards' (March 2000), 29-30.

105 Ibid., 3. 
recognized as relevant for 'sound financial systems', the Task-Force highlighted a 'subset' of twelve standards that were 'likely to make the greatest contribution to reducing vulnerabilities and strengthening the resilience of financial systems. ${ }^{106}$ This group of experts recommended that 'policy-makers' should focus on a 'list of standards' with 'priority implementation depending on countries' circumstances'.

In a footnote of its report, the Task-Force articulated the rationale of its decision-making by claiming that 'while a broad range of political, social, legal, and institutional factors impinge on financial stability, the focus of the FSF is on economic and financial standards which are generally accepted by the international community as being objective and relatively free of national biases, ${ }^{107}$ It is worth analysing how the Task-Force simultaneously distanced a group of norms from the list and brought other bodies of norms together. Indeed, it seems that the Task-Force had recourse to a 'knowledge practice'108 when it distinguished between, on the one hand 'political', 'social', 'legal' and 'institutional' norms, and on the other hand 'economic and financial standards for sound financial systems'. This practice of boundarydrawing enabled the Task-Force to carve out what it termed internationally accepted standards for economic, financial and market activities', creating distance from norms that did not fit in that category. ${ }^{109}$ This technique contrasts with straddling practices, that is, 'practices that straddle different bodies of norms without being seen to belong to either, thus blurring the boundaries between them'. ${ }^{10}$ However, straddling practices were also at play in the making of the Compendium. After distancing 'political', 'social', 'legal' and 'institutional' norms from the scope of its work, the Task-Force assembled 'the set of standards it considers the most relevant to strengthening financial systems'. By 'drawing on prior work' ${ }^{111}$ the Task-Force connected twelve standards to create something new out of this assemblage, namely a consolidated list of 'key standards for sound financial systems ${ }^{112}$

106 Ibid., 3.

107 FSF, 'Issue Paper of the Task-Force on Implementation of Standards', 7.

108 On 'knowledge practices' and their effects, see Riles, Collateral Knowledge.

109 FSF, 'Issue Paper of the Task-Force on Implementation of Standards', 7.

110 Chapter 1.

111 FSF, 'Issue Paper of the Task-Force on Implementation of Standards', 18.

112 Code of Good Practices on Transparency in Monetary and Financial Policies, Code of Good Practices in Fiscal Transparency, Special Data Dissemination Standard/General Data Dissemination System, Principles of Corporate Governance, International 
around which 'international consensus' had to be forged. This list of 'twelve key standards' then was the effect of a straddling practice, blurring the boundaries between the bodies of norms that were assembled in it. From the perspective of the Task-Force, the definition of this select group of bodies of norms as 'key international standards' was crucial to achieve international consensus. In this assessment, the Task-Force placed emphasis on those standards that were 'endorsed' by the 'international community', by which the Task-Force meant in particular national regulators, the IMF, the World Bank and international standard-setting bodies. In this way, the Task-Force brought into a mutual relation the standards that had been recognized as authoritative by the official sector of which the Task-Force itself was a part. As a creation of the FSF, the Task-Force included representatives of national governments, the IMF, the World Bank and the Basel Committee on Banking Supervision. By bringing together and giving weight to the standards that had been recognized by FSF members, international financial institutions and international standard-setting organizations, the Task-Force manifested a certain degree of selfreferentiality. ${ }^{113}$

The choice of focusing on standards produced and used by the 'official sector' (i.e. public actors) ${ }^{114}$ created distance from norms of private origin, with the exception of standards developed by the IASC and the International Federation of Accountants. The Task-Force framed the Compendium as a 'one-stop reference' to forge international consensus on 'key standards', limiting disagreement on their definition and with the aim of accommodating 'a large number of standards' that users could easily refer to. ${ }^{115}$ For the internal organization of the Compendium, the Task-Force preferred a 'web-based' structure to a hierarchical form to create linkages with a corpus of other 'relevant standards' that were 'not less important than the 12 key standards [...] but [were] complementary' to them. ${ }^{116}$ These complementary standards ought to be 'organized

Accounting Standards, International Standards on Auditing, Core Principles for Systemically Important Payment Systems, the Forty Recommendations of the Financial Action Task-Force, Core Principles for Effective Banking Supervision, Objectives and Principles of Securities Regulation, Insurance Supervisory Principles.

113 FSF, 'Issue Paper of the Task-Force on Implementation of Standards', 21.

114 IMF, World Bank, OECD, CPSS, FATF, BCBS, IOSCO, IAIS. Ibid., 19.

115 Ibid., 21.

116 Ibid., 20. 
separately' under three different categories. ${ }^{117}$ The Task-Force also envisaged that additional standards could be added to the Compendium as long as they were approved by relevant standard-setting bodies and FSF members. ${ }^{118}$

After the financial crisis of 2008, the creation by the G20 of the FSB as the successor of the FSF confirmed the forms of enmeshment construed when the Compendium was still in the making. The number of standards included in the Compendium grew considerably after the institutionalization of the FSB. As FSB members recognized new standards for 'sound financial systems', the boundaries of the Compendium expanded akin to the pages of a rule book, positing a distance between standards included in the Compendium and other bodies of norms that were kept outside. The incremental growth of the Compendium also strengthened the position of the FSB as an actor in the organization of standards recognized by the 'official sector'.

At the FSB, structures and dynamics of entanglement may depend on the actors involved in its decision-making. ${ }^{119}$ Here, the forms and content of interface norms may reflect the composition of the FSB but also the set of relations that the FSB has with other actors and institutions in the social and political environment in which it operates. With respect to membership, existing analyses have placed emphasis on the interactions between FSB members as central factors driving the activities of the FSB. Characterized by a broader membership than the FSF, the FSB has been portrayed as 'a nexus point' enabling interaction and communication between 'communities of private actors' and 'communities of states'. ${ }^{120}$ Stavros Gadinis has described it as 'an umbrella organization that brings together [...] networks of ministry executives, national regulators, and private professionals, ${ }^{121}$ placing emphasis on its strong ministry component. As such analyses have shown, state officials from the G20 and experts from standard-setting organizations have been the dominant

117 The categories that the Task-Force construed were: 'broad headings' (including macroeconomic fundamentals, institutional and market infrastructures, and financial regulation and supervision), 'policy areas' and 'functional areas'. Ibid., 21.

118 Ibid., 21.

119 On the centrality of actors in the construction of entanglements, see Chapter 1.

120 L. C. Backer, 'Private Actors and Public Governance beyond the State: The Multinational Corporation, the Financial Stability Board, and the Global Governance Order' (2011) 18 Indiana Journal of Global Legal Studies 751-802.

121 S. Gadinis, 'Three Pathways to Global Standards: Private, Regulator, and Ministry Networks' (2015) 109 American Journal of International Law 1-57, at 56. 
players shaping the agenda of the FSB. This dominance is reflected for example in the fact that there is a higher number of members from countries which are a part of the European Union than from other economies. $^{122}$

On the other hand, participation from market actors and publicprivate collaboration appear to be limited. According to the FSB's selfrepresentation, the degree of recognition of actors and norms of private origin seems rather limited. For example, the International Accounting Standards Board, formally a private organization, is a member of the FSB, and the International Financial Reporting Standards that they produce have been included in the Compendium of Standards. However, according to Annelise Riles, the FSB 'fails to recognize the practical authority of organizations such as the International Swaps and Derivatives Association in constructing their own forms of international financial governance beyond the state'. ${ }^{123}$ Thus, the interface norms construed within the Compendium are likely to be shaped by the convergence or competition of interests of the dominant public actors that have access to the FSB and by the wider institutional environment (i.e. the 'international financial architecture') in which the FSB itself is situated. For example, interactions between the FSB and the G20 may have consequences for the types of norms that are brought in relation in this context.

In the FSB context, straddling practices were not the only form of entanglement. Rather, conditional recognition practices originally performed by the Task-Force were also instrumental in organizing relations between 'key standards', the 'complementary standards' included in the Compendium and those yet to be included. Over time, FSB members have relied on a set of 'criteria for inclusion' to give weight only to standards deemed to be 'relevant', 'implementable', 'internationally recognized' and 'widely applicable'. ${ }^{124}$ However, the combined application of these criteria also consolidated a distinction between standards perceived to meet these criteria and standards which failed to do so. The interpretation of these requirements then had a rejection effect because it

${ }^{122}$ D. Arner and M. Taylor, 'The Financial Stability Board and the Future of International Financial Regulation', in R. Buckley, E. Avgouleas and D. Arner (eds), Reconceptualising Global Finance and Its Regulation (Cambridge University Press, 2016), pp. 51-66.

123 Riles, 'Is New Governance the Ideal Architecture', 257.

124 These criteria of recognition have been published on the website of the FSB. See www.fsb .org/work-of-the-fsb/about-the-compendium-of-standards/. 
distanced laws of private origin, which many actors use in their practices. For example, norms produced by the financial industry do not seem to be considered as relevant by FSB members, hence their absence from the Compendium. From this perspective, the 'criteria for inclusion of standards in the Compendium' may be seen as the content of an interface norm governing interactions between internal and external bodies of norms. In particular, the reproduction of this inside/outside distinction was performed by a reception norm whose content was a specific set of requirements defining 'the ways in which outside norms enter a given body of norms. ${ }^{125}$ In sum, it seems that straddling practices and reception norms played a more prominent role than overarching norms in the institutional site in which the Compendium took shape. The Compendium was the outcome of a work of composition that consisted of selecting, assembling and distancing bodies of norms. As the Compendium was still in the making, the Task-Force relied less on overarching norms than on straddling practices to perform this task. Such a form of entanglement makes sense because the task at hand was the creation of a new regulatory arrangement, in a context relatively free from pre-existing systemic constraints. Indeed, the project of a Compendium was in the first place the key innovation of the TaskForce and therefore its boundaries were still in flux. The effect of using this type of interface norm was closer to an assemblage type of order than to a system with clear institutional boundaries. However, the Task-Force also generated rules for the inclusion of 'international standards' and these criteria of recognition form the content of the reception norm that continues to order relations between the Compendium and external bodies of norms.

\subsubsection{Connecting International Financial Standards}

Financial regulators have also written reports containing recommendations that draw on previous reports or on documents written by other actors. The practice of drawing on other actors' bodies of norms have often had the effect of blurring their boundaries to create something new. Forms of entanglement have also been shaped in the context of institutional interactions between the FSB and international financial institutions. For example, FSB member jurisdictions have decided 'to undergo

125 See definition of 'reception norms' in Chapter 1. 
FSAP assessments every five years. ${ }^{126}$ FSB members have practised thematic and country-based peer reviews to assess compliance with international financial standards through a 'holistic approach'. ${ }^{127}$ These practices have followed the FSB Handbook for Peer Review and taken the FSAP's and Reports on the Observance of Standards and Codes' recommendations into account. ${ }^{128}$ In the context of these monitoring practices and 'peer reviews', acts of referring to the prescriptions of 'the other' have also blurred the boundaries between bodies of norms and enabled a mutual strengthening of their relations.

The straddling practice of compiling lists of international standards was not unique to the FSF/FSB as other actors and institutions beyond the FSB had recourse to similar techniques. ${ }^{129}$ Indeed, global governance practices through the creation of lists have also been common in other issue areas of global administration, for example international security. ${ }^{130}$ The Basel Committee on Banking Supervision issued a 'Compendium of Basel Committee documents', which was subsequently updated in 2001. ${ }^{131}$ In December 2019, the Committee published its 'Consolidated Framework' (referred to as 'Basel Framework') which embodies all fourteen standards it produced since its creation. ${ }^{132}$ Beyond its own norms, the chapter on 'Core Principles for Effective Banking Supervision' refers to other standards and practices, such as the recommendations by the IMF formulated in its FSAPs. ${ }^{133}$ These

126 See www.fsb.org/about/leading-by-example/participation/.

127 Gadinis, 'The Financial Stability Board', 161.

128 The Handbook for FSB Peer Review specifies that 'Country Reviews [...] examine the steps taken or planned by national/regional authorities to address IMF-World Bank Financial Sector Assessment Program (FSAP) and Reports on the Observance of Standards and Codes (ROSCs) recommendations on financial regulation and supervision.' See Standing Committee on Standards Implementation, 'Handbook for FSB Peer Reviews' (2017).

129 M. De Bellis, 'Global Standards for Domestic Financial Regulations: Concourse, Competition and Mutual Reinforcement between Different Types of Global Administration' (2006) 6 Global Jurist Advances, https://doi.org/10.2202/1535-1661 .1184 .

130 See, for example, G. Sullivan, The Law of the List: UN Counterterrorism Sanctions and the Politics of Global Security Law (Cambridge University Press, 2020).

131 Basel Committee on Banking Supervision, 'Compendium of Documents Produced by the Basel Committee on Banking Supervision' (May 2001).

132 Basel Committee on Banking Supervision, 'The Basel Framework' (December 2019).

133 'The regular reports by the IMF and the World Bank on the lessons drawn from assessment experiences as part of FSAP exercises constitute a useful source of information which has been used as an input to improve the Principles'. Footnote 40 at p. 28 of the chapter on Core Principles. 
practices have allowed shaping an entanglement between international financial standards and between these bodies of norms and domestic legal orders.

Basel Committee members encouraged taking account of anti-money laundering recommendations by the Financial Action Task Force (FATF). ${ }^{134}$ IOSCO, the Basel Committee and IAIS have blurred boundaries between their recommendations on combating money laundering and the financing of terrorism. In a joint statement, the three institutions claimed that the FATF 40 Recommendations provided a basis that would allow them to 'take account' of their respective standards in future work. ${ }^{135}$ The FATF, on the other hand, also took account of Basel Committee recommendations when it linked the 'customer due diligence' norm for banks originally crafted in 2001 by the Committee ${ }^{136}$ to its recommendations to combat money laundering. ${ }^{137}$ The language of 'taking into account' other standards reappeared in another statement, but this time the norms referred to were those of the FATF itself. ${ }^{138}$ Similarly, the interconnected structure of international standards has

134 '[S] upervisors should encourage the adoption of those recommendations of the Financial Action Task-Force on Money Laundering (FATF) that apply to financial institutions.' Basel Committee on Banking Supervision, 'Core Principles on Banking Supervision' (1997).

135 'The revised 40 FATF Recommendations will provide an opportunity for the standardsetting organizations to review their standards and guidance taking account of each other's work in this respect with the aim of preventing as far as possible inconsistencies between their standards and guidance where this is unwarranted from a risk-based approach.' The Joint Forum Basel Committee on Banking Supervision, International Organization of Securities Commissions, International Association of Insurance Supervisors, 'Initiatives by the BCBS, IAIS and IOSCO to Combat Money Laundering and the Financing of Terrorism - Joint Statement' (3 June 2003).

136 Basel Committee on Banking Supervision, 'Customer Due Diligence for Banks' (October 2001).

137 Following this, the BCBS stated that it was 'pleased to note the extent to which its publication Customer Due Diligence for Banks [...], has been reflected in the FATF's recommendations concerning customer due diligence. In all substantive respects, the spirit of the Committee's paper has been incorporated within the FATF approach.' Basel Committee on Banking Supervision, 'Basel Committee Welcomes Revised FATF Recommendations' (2003).

138 '[T]he IAIS adopted a Guidance paper on anti-money laundering and combating the financing of terrorism [...] The new guidance paper takes into account the revised FATF 40 Recommendations of June 2003 and the Methodology for Assessing compliance with the FATF 40 recommendations and the 8 special recommendations issued in February 2004, as well as the 8 Special Recommendations on Terrorist Financing of October 2001.' The Joint Forum: Basel Committee on Banking Supervision, International Organization of Securities Commissions, International Association of 
been emphasized by private norm addressees in financial markets. ${ }^{139}$ These statements have been subtle conduits in the discursive enmeshment of financial standards. Financial regulators and producers of those standards have often construed standards in connection with other standards, which suggests that these norms have become entangled in an interconnected 'web' of norms. ${ }^{140}$ As we have seen, the web-like shape of the Compendium equipped with hyperlinks to enable users to connect to the webpages of the different standard producers (and their standards) was indeed foreseen by the Task-Force on Implementation of Standards. This particular feature enabled users of the Compendium to create loose, ad hoc connections between standards through their statements and practices. It may be that this particular way of constructing relations between bodies of norms was done for strategic reasons, perhaps to strengthen the authority of the technical bodies that make those standards, including standard-setting organizations that are members of the FSB itself. ${ }^{141}$

\subsection{Conclusion}

This chapter has focused on forms, locations and practices in which relations between bodies of norms in global financial governance have been defined in the aftermath of the Asian financial crisis and the global financial crisis. Drawing on official pronouncements connected to the IMF, the UN and the BIS, it has observed the different contexts in which these relations have come about. The institutional memory examined has provided traces of ad hoc but not uncontroversial construction of entanglements and the participants and factors behind them. In many of the sites of governance examined, different forms were articulated through dynamic and informal interactions of a multiplicity of

Insurance Supervisors, 'Initiatives by the BCBS, IAIS and IOSCO to Combat Money Laundering and the Financing of Terrorism Update - Joint Statement' (2005).

139 The European Banking Federation has referred to the plurality of norms contained in the document 'Basel III: Finalising Post-Crisis Reform', which they call Basel IV, as a 'package'. See EBF, 'Summary on Basel IV in Europe' (2019).

140 Chapter 1.

141 Previous work has suggested that international standards might be 'mutually reinforcing' through practices of cross-referencing and incorporation. See De Bellis, 'Global Standards for Domestic Financial Regulation'. On this 'strategic' path to entanglement, see Chapter 1. 
regulators, international institutions and international standard-setting organizations involved in the global governance of financial stability.

Competing ordering projects have emerged in different contexts in the theory and practice of global financial governance over time. These projects were also sites in which actors imagined different ways of shaping 'international standards' and their relations, with implications for the forms of entanglement that came about through their claims. Since the second half of 1990s, the multiplication of standards deemed to be relevant by financial regulators has triggered efforts to define their relations, and regulators have relied on different interface norms at different sites of governance to create order. International lawyers have often imagined the global financial order from an intra-systemic perspective and sought to organize institutional pluralism through overarching norms such as the rule of law.

Although many of the actors analysed imagine a global financial system, there is a lack of general agreement on the implications for the relations between different bodies of norms. Differently situated actors defined their relative weight in different ways by placing emphasis on different norms and sites of authority. For example, in their respective ordering projects in response to multiplicity, officials at the UN, the IMF and at the BIS have come up with conflicting views on the position of the relevant sites of authority. From this perspective, the emerging overall order remains pluralistic.

Drawing on the history of the Compendium of Standards, differences between forms of entanglement connected with the Financial Stability Forum and those linked to the IMF and UN contexts could be observed. Standards included in the Compendium were ordered through an interplay of straddling practices and reception norms. When the Compendium was still in the making, the former type of interface norm appeared in the work of the Task-Force on Implementation of Standards. In this context, boundary-drawing practices, too, were used to create distance from norms that actors assembled at the FSF did not identify as relevant. By contrast, other bodies of norms were connected to form an official list of international financial standards, around which an international consensus had to be built. The making of a list of 'twelve key standards' was the outcome of a straddling practice by the Task-Force, which had the effect of blurring the boundaries between the bodies of norms that were brought within this new list. However, the increasing institutionalization of the FSB has been coupled with a greater emphasis on practices of regulatory uniformity and centralization. Through the 
Compendium of Standards, regulators assembled at the FSB sought to provide a common frame to respond to the dilemmas of proximity and difference of bodies of norms in global financial governance. Over time, the FSB has sought to bring together multiple monitoring practices and their bodies of norms within a single overarching 'framework'. ${ }^{142}$ From this perspective, it seems that a hierarchical ambition has also been at play.

However, institutional pluralism provoked similar responses in other settings, too, which triggered further forms of entanglement through the production of further compendia, lists, and rule books to order relations between bodies of norms for global financial stability. The emerging picture is heterogeneous, as evidenced by the absence of a single global decision-maker, the coexistence of different plans for reform and different visions of the relevant sites of decision-making and forms of authority.

${ }^{142}$ FSB, 'Framework for Strengthening Adherence to International Standards' (January 2010); FSB, 'A Coordination Framework for Monitoring the Implementation of Agreed G-20/FSB Financial Reforms' (2011). 